\title{
Open Innovation of Institutional Investors and Higher Education System in Creating Open Approach for SDG-4 Quality Education: A Conceptual Review
}

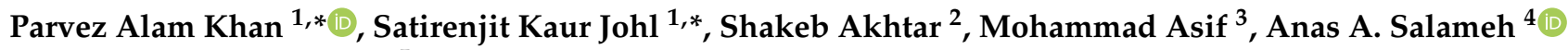 \\ and Thavamaran Kanesan 5 \\ 1 Department of Management and Humanities, Universiti Teknologi PETRONAS, \\ Seri Iskandar 32610, Perak, Malaysia \\ 2 Department of Finance, School of Business, Galgotias University, Greater Noida 203201, Uttar Pradesh, India; \\ shakebakhtar.amu@gmail.com \\ 3 Department of Finance, College of Administration and Financial Sciences, Saudi Electronic University, \\ Riyadh 1167, Saudi Arabia; asif.alig35@gmail.com \\ 4 Department of Management Information Systems, College of Business Administration, Prince Sattam Bin \\ Abdulaziz University, Al-Kharj 11942, Saudi Arabia; a.salameh@psau.edu.sa \\ 5 Executive Office, Proofreading by A UK Ph.D., Cyberjaya 63000, Selangor, Malaysia; \\ drthava@proofreadingbyphd.com \\ * Correspondence: parvezkhan.alam@gmail.com (P.A.K.); satire@utp.edu.my (S.K.J.)
}

check for

updates

Citation: Khan, P.A.; Johl, S.K.;

Akhtar, S.; Asif, M.; Salameh, A.A.;

Kanesan, T. Open Innovation of Institutional Investors and Higher Education System in Creating Open Approach for SDG-4 Quality

Education: A Conceptual Review. J. Open Innov. Technol. Mark. Complex. 2022, 8, 49. https://doi.org/10.3390/ joitmc8010049

Received: 25 January 2022

Accepted: 1 March 2022

Published: 4 March 2022

Publisher's Note: MDPI stays neutral with regard to jurisdictional claims in published maps and institutional affiliations.

Copyright: (c) 2022 by the authors. Licensee MDPI, Basel, Switzerland. This article is an open access article distributed under the terms and conditions of the Creative Commons Attribution (CC BY) license (https:// creativecommons.org/licenses/by/ $4.0 /)$.

\begin{abstract}
The introduction of sustainable development goals has made sustainability a top priority for most nations. This has raised the investment into the educational system for potential growth and for creating an innovation culture in any country; the role of institutional investors in the development of financing clean energy infrastructure, entrepreneurial development, poverty reduction, and driving corporate social responsibility and firm development has been found significant. An intensive literature search of Scopus and the web of science database was explored with different relevant sets of keywords "Institutional investors AND Education", "Institutional investors" AND "Higher education", which drew 29 final articles between 2010-2021. This scoping review draws a new open approach for creating alternative sustainable funding for the higher education system and investment opportunities for institutional investors with government intervention. This research becomes the first that shows the road map to the higher education system in creating alternative funding through the proposed Institutional Investor \& Sustainable University Funding Governance Code, which will make the higher education system independent and ease the burden on the government, as well as create a huge market opportunity for both players. This research model will scope the collaborative approach towards sustainable development goal 4-Quality education.
\end{abstract}

Keywords: sustainable development goal; SDG-4 quality education; institutional investors; higher educational

\section{Introduction}

Open innovation is topical in major areas of research, for instance, environment and social innovation [1-3], Promoting Digital Entrepreneurship [4], Internal Corporate Responsibility [5], and the role of universities in open innovation research [6].

Similarly, the open approach is also gaining momentum in higher education in terms of value co-creation from the collaboration industry and higher education [7,8], and research and innovation [9]. Higher education is one of the most significant indicators of global competitiveness. In response to globalization and the so-called "knowledge economy", many countries have attempted to improve international competitiveness by developing and modifying macro policies to strengthen higher education, particularly universities, a core component of the education sector. However, the educational system across the world has 
been immensely affected due to this outbreak of COVID-19, the most affected around the globe is the education system (Colleges and Universities) [10] and their financials [11,12].

Apart from the COVID-19 pandemic, there are several other challenges the world is facing, which can be assessed by looking at United Nations 17 sustainable development goals (SDG) 2030 [13-17]. The sustainable development goals (SDGs) are a blueprint for a better and more sustainable future for everyone (UN SDGs 2015) [18-20]. In which the United Nations has developed 17 challenges in terms of goals and 169 targets to be active by 2030 [21-24], the SDG17 includes quality education Goal 4. Quality education goal (SDG-4) is at four, after eradication of poverty (SDG-1), zero hunger (SDG-2), and good health and wellbeing (SDG-3) [20,22,25].

The priority on quality education is due to the surprising fact that globally [26], 258 million children are out of school, and 617 million youth worldwide lack basic literacy and math skills despite being in school (USI 2018), whereas the 2030 agenda for sustainable development is universal, holistic, and indivisible, with a particular focus on ensuring that no one is left behind. SDG-4-Ensure inclusive and equitable quality education and promote lifelong learning opportunities for everyone (Nation 2019). Similar in line with the global effort for quality education, several attempts are also made by every government of the country. For instance, open [27], several initiatives for educating girls in India [28], and for students with disabilities in South Africa [29].

Similarly, the Saudi Arabian government has priorities on higher education in the evidence of Vision 2030 for Saudi development [30]; there were 36 education plans developed in the year 2020 by the Saudi government to achieve Vision 2030. This vision includes teacher-student training and development, development of financing methods and improvement in financial efficiency, and increasing private sector participation in the education sector [31].

The invitation of private sector participation shows that all related parties are necessary at this time, and there is also the significant requirement of funds coming directly apart from the Saudi government. This research propounds a new model for the higher education of the alternative funding opportunity from private investors and other funding sources for the educational institutions, which will create a stable investment opportunity for institutional investors and revive the higher education system post-COVID-19 without impacting the government fund.

The literature on funding education institutions by institutional investors is not comprehensive to date. The current literature review has yielded evidence of private grants and funding for ideas and projects; it is also noted that collaborative research and development projects are being conducted in the interests of resource-sharing with multinational companies (private and public), but there is little research highlighting the role of institutional investors in funding educational institutions in Saudi Arabia.

To achieve successful institutional investment into educational institutions, there is a need to establish the idea and explore possibilities of the institutional investors to support the Saudi Arabia 36 plans for the year 2020 for achieving the education initiatives listed under Saudi Arabia's Vision 2030 [32].

The institutional investment will act as alternative funding for educational institutions, and the Saudi education system will receive further support for its operational and research development activities. This will boost the Saudi education system's institutional ranking and contribute directly to sustainable development goal 4 (SDG-4) of achieving quality education; however, there are several challenges [33] in achieving SDG-4, but on the contrary, there are several opportunities as well that will emerge from inviting institutional investors.

Therefore, there is a pressing need to invite institutional investors to offer alternative educational funding in several ways, for instance, initial Public Offering (IPO) or via bonds, mutual funds, insurance, or real estate investment. This initiative will also boost the country's economy, attract foreign investors, and achieve societal development without requiring extra investment by the government or further tax burden to Saudi Arabia. 
This proposed research model will also create alternative funding for universities, which will boost the university's (and, by extension, the education system's) capabilities in infrastructure development, faculty development, and laboratories. This will generate returns in the forms of publications, patents, and commercialization of the university's discoveries and inventions. This research model will also tie in closely with the industries so that the research taking place would be assuredly useful in business and practical applications. This proposed research model also brings about new possibilities in filling the gap between industry and educational institutions, bringing greater opportunity for industry or private institutions to invest and develop educational institutions and their stakeholders.

On the other hand, in return for investments, this research model creates more collaborative patents, trademarks, and innovative products for institutional investors that will allow institutional investors to generate revenue. Finally, this research model creates a win-win situation for both parties and eases the burden on government expenditure towards creating a better education system.

The paper flow has the methodology section, the systematic literature review process for framework development, it creates a nexus of institutional investors and educational institutions, highlights the role of the government in developing a new model of alternative fundings and opportunities for the institutional investor, followed by a discussion section.

\section{Materials and Methods}

Literature review papers play an essential role in the overall diffusion of knowledge in any academic sector. They give the researcher a thorough awareness of the topic and its extent for future research possibilities. Author [34] pointed out the literature review process must have a greater level of transparency through comprehensive content analysis of all related articles; for this, we have explored the oldest indexing database Scopus and web of science with the combination of keywords of "Institutional investors AND education", "Institutional investors" AND "Higher education" for developing a novel conceptual review.

This article has explored this WoS and Scopus database, the largest, oldest indexing databases [35], they are widely utilized in several review articles [36,37].

In this search of both databases, we found 35 articles from the Scopus database and 27 articles from the web of science database. After this, we eliminated duplicates and conference articles ( 6 articles), which gave us 29 articles that discussed the education sector and institutional investors in the article.

However, to the best of the authors' knowledge, none of the research proposed inviting institutional investors to invest as alternative sustainable fundings for higher education.

In the literature search, we did not find the lead author as all the authors have just one article each in the database, and most of the research was conducted in 2021. The details are graphically presented in the Figure 1 given below.

Figure 2 shows that there have been minimal studies since 2010; the highest number of studies has been seen in the current year 2021. The merge of institutional investors and education is the niche to explore the top authors because all the related authors have only one article each. It is difficult to say which author is the lead author. Figure 3 shows the lead journals, and Figure 4 shows the lead authors. From Figure 3, Frontier of Business Research in China has topped the journal list with a publication score of 2 , and the rest have only 1 publication score. 


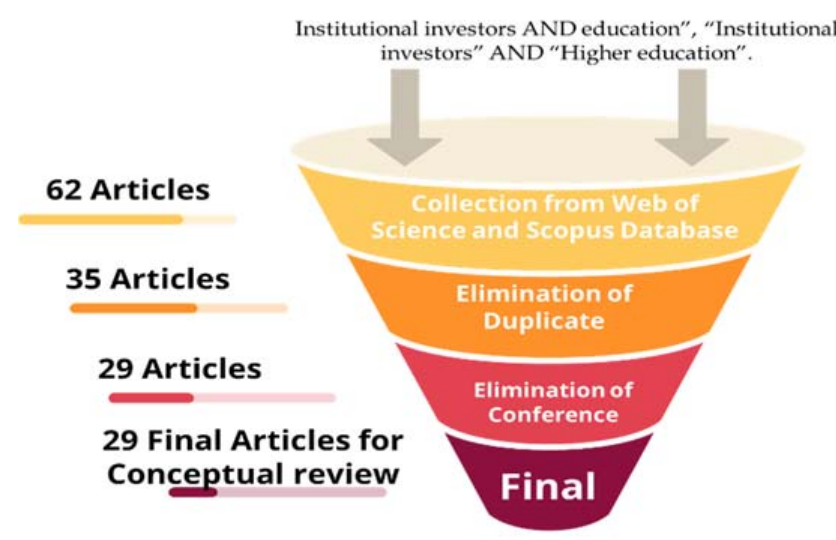

Figure 1. Flow Diagram of Article Selection for Conceptual Review.

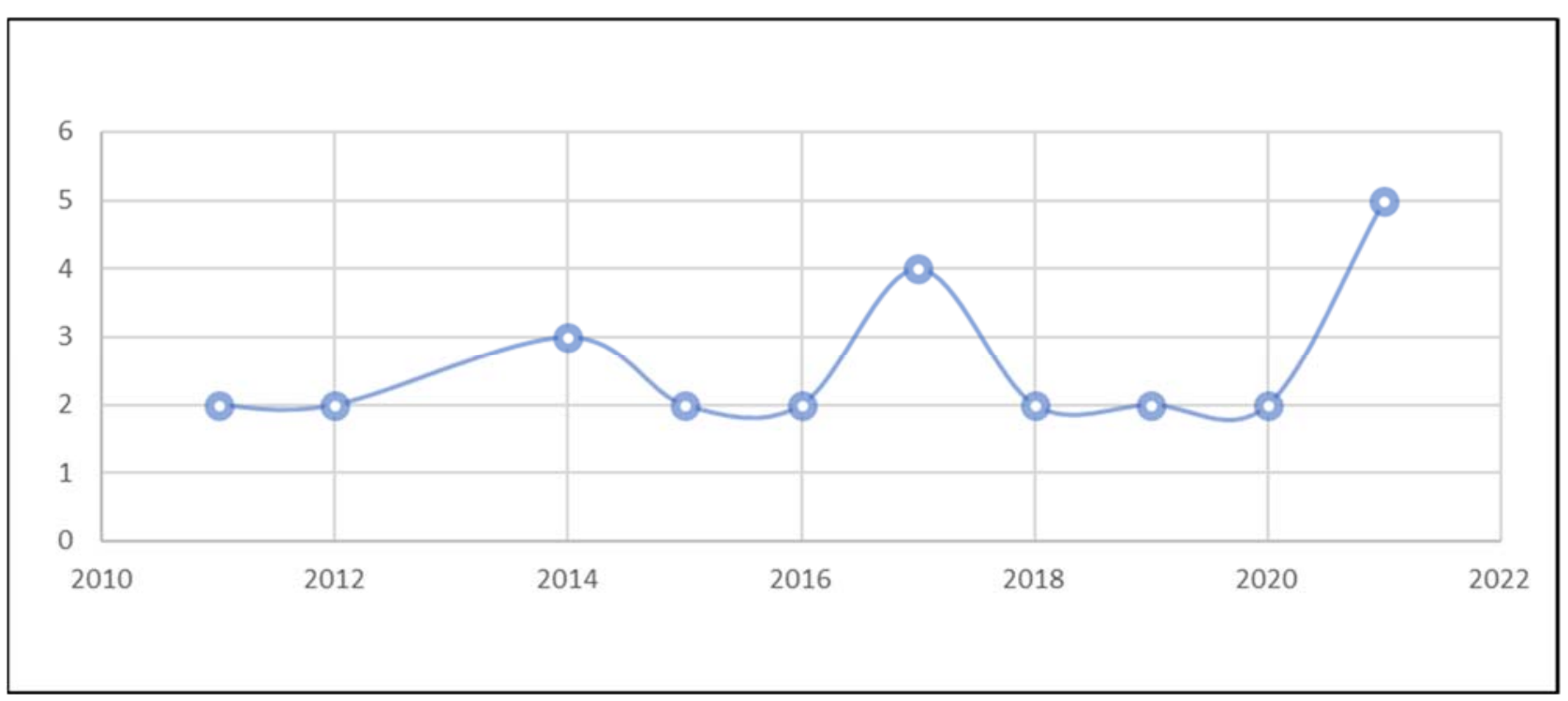

Figure 2. Number of Articles.

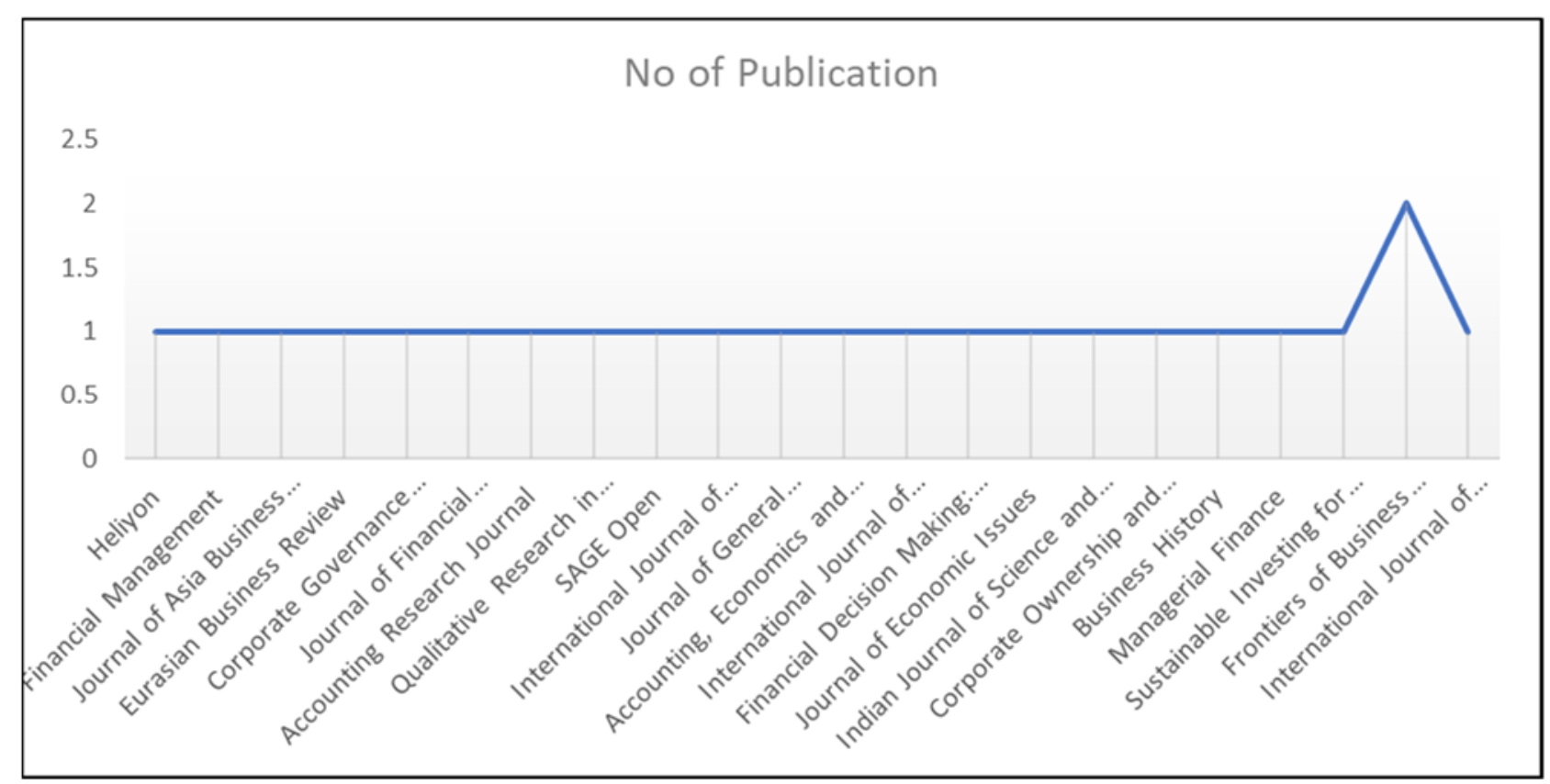

Figure 3. Top Leading Journals. 


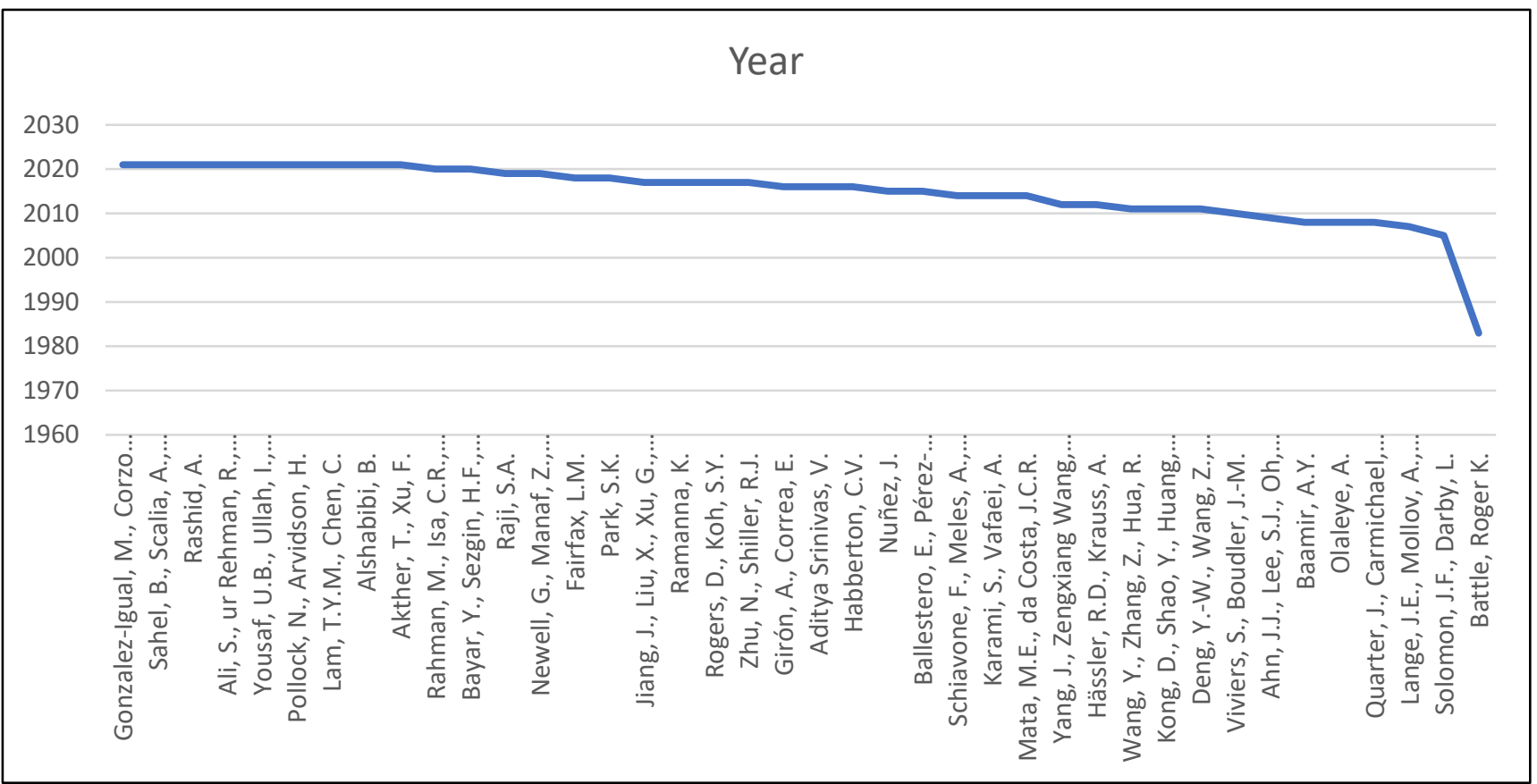

Figure 4. Lead Authors.

In addition, several authors adopted a visual representation of bibliographic coupling author citation shown by several review articles [38,39]. Similarly, this review article has also shown a visual representation of bibliographic coupling authors in Figure 5, which indicates around 40 clusters. However, the main five clusters are authors AHN, J.J CHOWDHURY, N.T, AHMAD, M.I AND BYGRAVE, W.D.

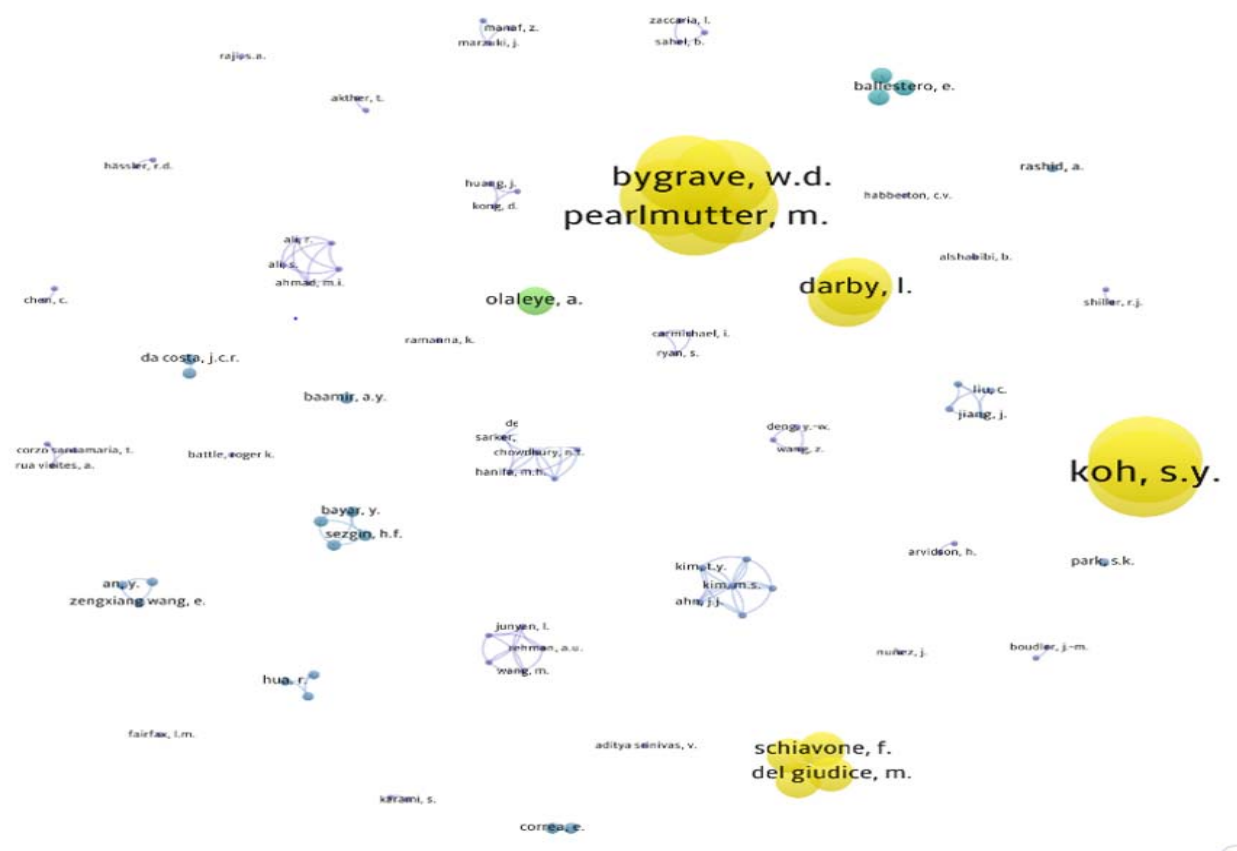

Figure 5. Visual representation of bibliographic coupling; Author.

The visual representation of the bibliographic coupling of citations in Figure 6 shows that the highest average years of citation is led by authors BYGRAVE, W.D, PEARLMUTTER.M, KON, S.Y, DARBY, I AND SCHIAVONE, F. DEL GIUDICE, M. However, this is an 
emerging area of research, therefore, there is limited research stating the relationship of institutional investors' roles in higher education. After a basic literature search of Scopus and the web of science database, the following section involves building a theoretical framework by segregating the articles on institutional investors and alternative fundings for higher education.

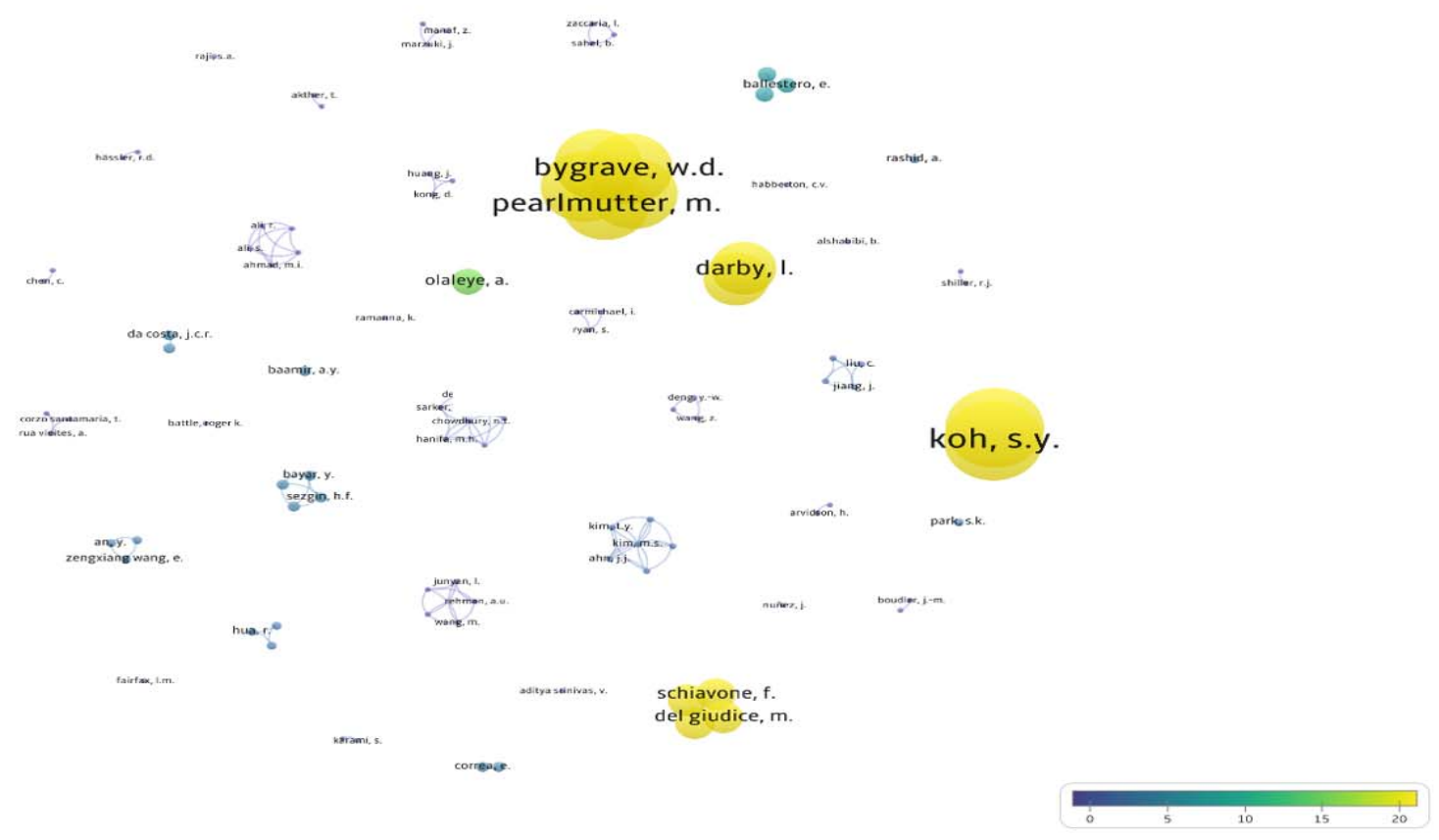

Figure 6. Visual representation of bibliographic coupling; Citation.

This narrative literature search also proposes the need for a new model in the education system and code of governance to establish alternative funding, an open investment approach, and create a win-win situation for all stakeholders. The following section will establish the theoretical framework.

\section{New Theoretical Framework Development}

The alternative funding opportunity and investment opportunity in the higher education system is the novelty of the research, which can be clearly seen in the detailed literature of institutional investors and their interest in sectors other than the education sector.

Table 1 of the literature review in the field of institutional investors shows the positive role of banks, insurance companies, and private pensions in the development of clean energy [40], mutual fund and hedge funds in the development of China stock market [41], as well US firms [42]. It also shows the role of institutional director investors' banks in positive CSR [43] and lastly Institutional climate finance, low carbon investment in minimizing the carbon footprints [44]. 
Table 1. Literature review in the field of institutional investors.

\begin{tabular}{|c|c|c|c|c|}
\hline $\begin{array}{c}\text { Institutional } \\
\text { Investor's Variables }\end{array}$ & Industry & Impact (Finding) & Practical Implications & Reference \\
\hline $\begin{array}{l}\text { Bank, Insurance \& } \\
\text { Private Pensions }\end{array}$ & Clean Energy & $\begin{array}{l}\text { Positive effect on financing } \\
\text { clean energy and Climate } \\
\text { change mitigation }\end{array}$ & $\begin{array}{l}\text { Need to scale up the green } \\
\text { bond, investment funding } \\
\text { structure for } \\
\text { risk-mitigating public and } \\
\text { private finance } \\
\text { mechanisms }\end{array}$ & {$[40,45]$} \\
\hline $\begin{array}{l}\text { Insurance, Mutual } \\
\text { Fund, Pension Fund, } \\
\text { Foreign Inflows }\end{array}$ & Economic Growth & $\begin{array}{l}\text { In industrialized economies, } \\
\text { institutional investors have a } \\
\text { positive effect on the growth of } \\
\text { GDP per capita }\end{array}$ & & {$[46,47]$} \\
\hline Mutual Fund & China stock market & $\begin{array}{l}\text { Effective monitoring } \\
\text { mechanism, deterring fraud, } \\
\text { and enhancing corporate } \\
\text { governance in Chinese } \\
\text { capital markets }\end{array}$ & & [41] \\
\hline $\begin{array}{l}\text { Mutual Fund Hedge } \\
\text { Fund }\end{array}$ & US Firm & $\begin{array}{l}\text { Firms deleverage by reducing } \\
\text { debt and transitioning to debt } \\
\text { associated with enhanced } \\
\text { monitoring and efficiency }\end{array}$ & & [42] \\
\hline $\begin{array}{l}\text { Institutional Director } \\
\text { Investors -Bank }\end{array}$ & $\begin{array}{l}\text { Corporate social } \\
\text { responsibility reporting } \\
\text { (CSR) }\end{array}$ & $\begin{array}{l}\text { Increase environmental and } \\
\text { social commitments, Minimize } \\
\text { the probability of default, and } \\
\text { maintain prestige and } \\
\text { professional reputation }\end{array}$ & & [43] \\
\hline $\begin{array}{l}\text { Institutional Climate } \\
\text { Finance, Low Carbon } \\
\text { Investment }\end{array}$ & Low carbon Investment & $\begin{array}{l}\text { Positive Impact on Climate } \\
\text { finance-Improving Pricing } \\
\text { and Market efficiency }\end{array}$ & $\begin{array}{l}\text { Transparency is Not } \\
\text { enough-It addresses only } \\
\text { behavioral basis, but the } \\
\text { strategic limitation is more } \\
\text { serious }\end{array}$ & [44] \\
\hline $\begin{array}{l}\text { Public and Private } \\
\text { Institutional Investor }\end{array}$ & $\begin{array}{l}\text { Social Infrastructure } \\
\text { Investment }\end{array}$ & $\begin{array}{l}\text { Positive improvement and } \\
\text { expansion of sustainability, } \\
\text { Sustainable development goal }\end{array}$ & $\begin{array}{l}\text { Open door for Sustainable } \\
\text { development goal } \\
\text { investment for the asset } \\
\text { owner }\end{array}$ & [48] \\
\hline $\begin{array}{l}\text { Foreign Investor and } \\
\text { Pension Fund }\end{array}$ & $\begin{array}{l}\text { International } \\
\text { companies }\end{array}$ & $\begin{array}{l}\text { Foreign Investor pension fund } \\
\text { and other has positive } \\
\text { relevance in information } \\
\text { discloserGovernment and } \\
\text { financial institutions and } \\
\text { crossholding do not have an } \\
\text { impact on the } \\
\text { Information system }\end{array}$ & $\begin{array}{l}\text { Participants of } \\
\text { Government and financial } \\
\text { institution and } \\
\text { crossholding need } \\
\text { to scaleup }\end{array}$ & [48] \\
\hline
\end{tabular}

This literature research draws the attention of government education policymakers for sustainable alternative funding from institutional investors and alternative investment opportunities for institutional investors, after the systematic analysis of the role of institutional investors in different industries $[40,41,49]$ and their impact in Table 1.

Table 1 shows the potential of an institutional investor, therefore proposes to create an opportunity for both the higher education system and institutional investor.

Several factors will affect the impact of institutional investors on the education sector, namely, low expectations from the education-based stock market, adequate adjustments to the education market, loss experience, and assumption of a stable education market [50,51]. 
This investment is an alternative opportunity for the university to develop infrastructure and academic research and development.

Compared with industrial research and development, university research tends to be more aligned with the basic purpose of research and development (R\&D), which is an opportunity for institutional investors to invest in the educational sector. In contrast, industrial research, and development focus more on obtaining private benefits for related enterprises. It is believed that a company's industrial R\&D will bring some "spillover benefits" to other companies, which often discourages the company's investment. It can be expected that this kind of spillover income from university research will significantly increase because they have no incentive to keep research privatized. In fact, scholars are strongly motivated to publish their findings, following which, institutional investors may help commercialize the innovation.

On the contrary, research into alternative funding [52-54] to the educational sector found a few alternative investments with a positive effect on the whole education system as well as an individual, but there is a lack of research on the role of specifically institutional investors on funding the education system of any country. Table 2 shows the funding sources as Waqf, Community support, Zakat Funding, Equitable Funding, and Public Funding apart from direct government funding.

Table 2. Literature Review in funding sources to the education system.

\begin{tabular}{|c|c|c|c|}
\hline $\begin{array}{l}\text { Source of Funding to } \\
\text { Education System }\end{array}$ & (Finding) & Practical Implications & Reference \\
\hline $\begin{array}{l}\text { Funding higher education } \\
\text { through waqf- Private and } \\
\text { Public Waqf }\end{array}$ & $\begin{array}{l}\text { Positively Meet the expenditure } \\
\text { through WAQF funding (Private } \\
\text { and Public) }\end{array}$ & $\begin{array}{l}\text { Source of social financing } \\
\text { alternative fiscal instrument for } \\
\text { funding in higher education }\end{array}$ & [55] \\
\hline Community Support Funding & $\begin{array}{l}\text { Positively impacting on investment of } \\
\text { building, and primary expenses } \\
\text { (salary payment, bill, and furniture) }\end{array}$ & $\begin{array}{l}\text { Support to ease the burden on } \\
\text { the government of Nigeria }\end{array}$ & [56] \\
\hline Zakat Funding & $\begin{array}{c}\text { Positive on induvial and } \\
\text { education system }\end{array}$ & & [57] \\
\hline Equitable Funding & $\begin{array}{l}\text {-Possibility to reform the education } \\
\text { system through Equitable } \\
\text { funding.-Research depicts equitable } \\
\text { allocation model is considerably more } \\
\text { than positive achievement level }\end{array}$ & $\begin{array}{l}\text { Education Leaders need } \\
\text { flexibility and creativity in } \\
\text { traditional funding }\end{array}$ & [58] \\
\hline Public Funding & $\begin{array}{l}\text { Positive findings on individual } \\
\text { welfare not as a whole of } \\
\text { Higher education }\end{array}$ & & {$[58,59]$} \\
\hline
\end{tabular}

Therefore, both tables of literature on the role of institutional investment and alternative education funding confirm the gap in the literature that there is a pressing need to open approach for institutional investors to alternative educational funding in the way of Initial public offering (IPO), bond, mutual fund, insurance, and real estate investor or any alternative way should be explored to bring the opportunity for both parties.

\subsection{Nexus Institutional Investor and Educational Institution: Adoption of Open Approach}

The growth of the Indian stock market [60], financing clean energy infrastructure, entrepreneurial development, poverty reduction [61] and driving corporate social responsibility [62], and firm performance are proof of the tremendous role institutional investors play in reforms and improvements. There is also other evidence in the literature review of institutional investors and contributions, for instance, improvement of corporate governance quality [63], achieving sustainable development goals [64] and mitigating climate change risks $[59,65]$. 
Likewise, the invitation of institutional investment is critical in establishing sustainable funding for universities. The role of institutional investors, such as banks, hedge funds, mutual funds, or real estate investment trusts, will enhance the financial standing of the education system, enabling universities to offer quality education, research and development, and innovative culture contributing to societal development. Inviting institutional investors for alternative funding to the education system will not only contribute to the development of universities but also make the education system independent. This would mean that government funding can be utilized in other economic development initiatives, such as attracting foreign talent for research, university collaboration with top universities, and commercializing research and patents.

This initiative will also ease the burden on the government with regards to the education budget, on which most countries spend $1 \%$ to $5 \%$ of the country's GDP. These funds can be diverted to other socio-economic development plans for the country or can be utilized as per the independent objectives of each country [66]. This initiative will offer the investment opportunity for both the higher education system and institutional investors of the country, which will act as a blue ocean strategy by the government where an investor can find a new market for investment and return under the government's governance. Therefore, this research proposes the following model of sustainable funding for universities and investment opportunities for institutional investors (Figure 7).

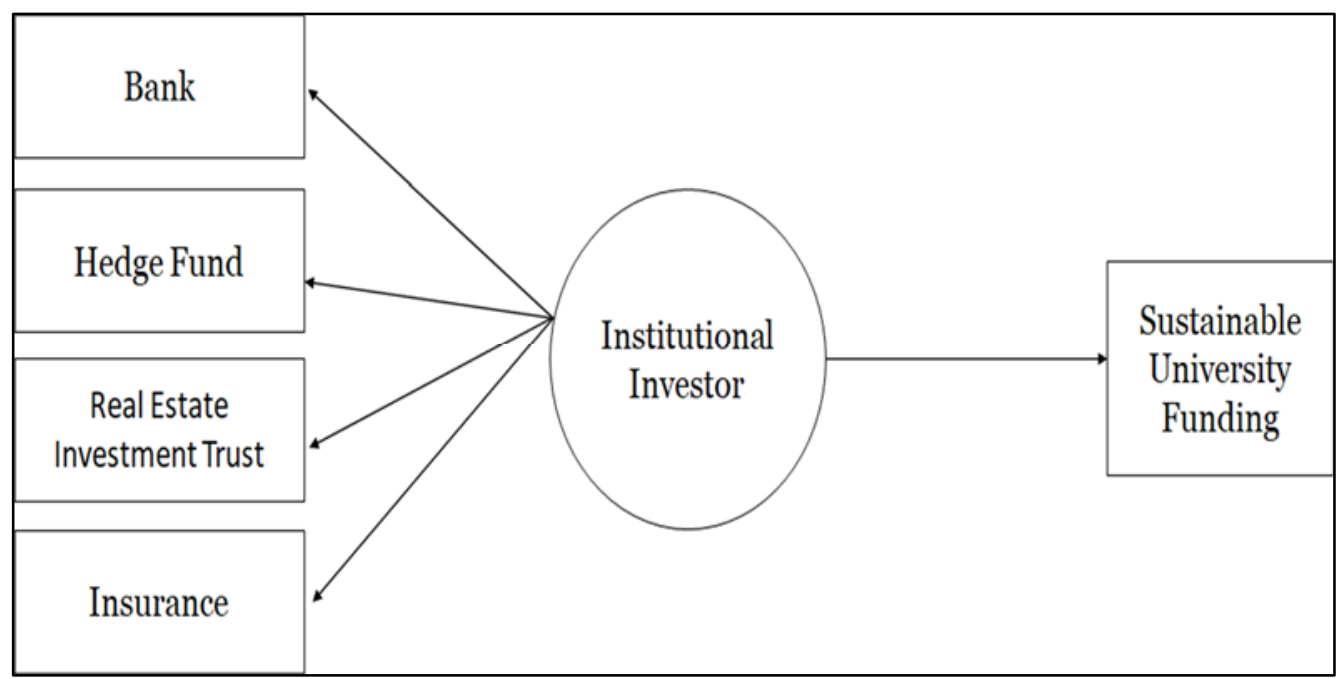

Figure 7. Institutional Investor and University Sustainable Funding.

\subsection{Use of Alternative Funding from Institutional Investors}

According to the 2015 Frascati Handbook, research activities must be novel, creative, uncertain, systematic, transferable/reproducible, and all activities must be performed to produce new knowledge. Based on these attributes, as well as the definition of research and innovation outlined above, the following list reflects the general research activities funded by institutions that the university may assign budgets to:

- Development and implementation of research-related training.

- Support professional, technical, administrative, or clerical support personnel engaged in activities.

- Essential to R\&D.

- Upgrade and purchase of equipment and facilities.

- Participate in conferences and seminars.

- $\quad$ Supervise R\&D projects and research higher education students' programs!

- Mobility of researchers and research support staff for temporary cross-industry or cross-institutional contacts for knowledge transfer.

- $\quad$ R\&D projects in cooperation with external stakeholders who need or participate in $R \& D$. 
- Patent application and intellectual property licensing work.

- Prototype development and testing.

- Market survey.

- License Marketing.

- Technical evaluation.

- Phases 1 to 3 of clinical trials (as defined in the 2015 Frascati Handbook)

- Develop application software, new programming languages, and new operating systems.

Therefore, the role of institutional investors and a sustainable university funding model will bring a revolution to the funding of education systems and contribute directly towards social development specifically to SGD 4-achieving quality education, this research model can be named the Institutional Investor and Sustainable University Funding (II-SUF) model. In this proposed model, the insurance company's role is seen in the university context as providing insurance to the students and staff, which can help with the positive acceptance of institutional investor participants in universities. Likewise, other institutional investors like banks can also act as investors in academic research and development as partners, leading to new banking businesses apart from their usual traditional product offerings. Banks can also do their own due diligence and in-depth assessments before funding the projects.

In addition, alternative investment firms such as mutual funds, hedge funds, and real estate investment trusts can also contribute towards research collaboration and funding to create a new market. While current university practices do not currently support the opportunity for mutual and hedge funds to provide such support yet, there is evidence that real estate investment trusts have funded university infrastructure development before [67]

Therefore, the role of institutional investors and sustainable university funding model will bring revolution in the funding to the education system and contribute directly to social development, specifically to SGD 4-achieving quality education.

\subsection{Academic Institutions and Their Entrepreneurial Plans to Attract Institutional Investors of KSA}

This research model also promotes the development of entrepreneurs in Saudi Arabia. Authors [68] have advocated the role of Saudi universities in developing the country's entrepreneurial leadership in his research. Another author [69] points out that university entrepreneurship education has a significant positive impact on the financial performance of graduate entrepreneurs [69].

Author [70] has emphasized in their research that entrepreneurship education is a tool for acquiring professional qualities and boosting entrepreneurs' long-term competitive advantage. Entrepreneurship education is a definite positive influence on the institutional investors in the education system in Saudi Arabia and will become a near-term alternative investment opportunity. Author [71] points out that entrepreneurship education directly affects financial knowledge and positively affects entrepreneurial skills. In addition, research [72] mentions that entrepreneurial education affects money literacy.

Furthermore, the Kingdom of Saudi Arabia plans to have five Saudi universities among the top 200 universities globally by the year 2030, which has in brought the government's focus to strict literacy, character, and numeracy standards in modern curricula to inculcate ethics [73]. This planned goal will not enhance the literacy and skill of the citizen but also increase the entrepreneurial culture leading to economic move for betterment.

In the research, Ref. [68] mentions in their research that Saudi universities play a key role in entrepreneur development, and King Abdulaziz University, established by the Saudi Arabian government, assists entrepreneurs in developing entrepreneurial leadership skills. Abdulaziz University is known for promoting innovative business ideas to students and businessmen. King Fahd University of Petroleum and Minerals plays a leading role in building a network of entrepreneurs and alumni, which is leading an entrepreneurial academy to help improve entrepreneurial leadership. Prince Mohammed Bin Farhad University, Umm Al Qura University, and King Saud University have all played vital 
roles in developing intellectuals and enabling them to have the right skills to become entrepreneurs.

\section{Moderation: Role of Government in Open Approach}

This section brings out another important player the "government" for implementing this model in Saudi Arabia education. The moderating role of government intervention will develop a system of governance and act as a watchdog to meet the all-party interests, government intervention is needed [74], as it is a matter of the improvising country's education system and creating funding opportunities, which requires the monitoring to maintain quality, conflict management, stakeholders' management for a sustainable education system. This research model is incomplete and impractical without the role of the government, as only a governing authority can invite an institutional investor to invest in the national education system and the institutional investor will be able to develop confidence in capital investment.

In this research model (Figure 8), the government intervention will act as a moderator, enhancing the value creation for institutional investors and alternative sustainable funding. This initiative requires an Institutional Investor and Sustainable University Funding Governance Code (II-SUF Code) that establishes accountability of both parties.

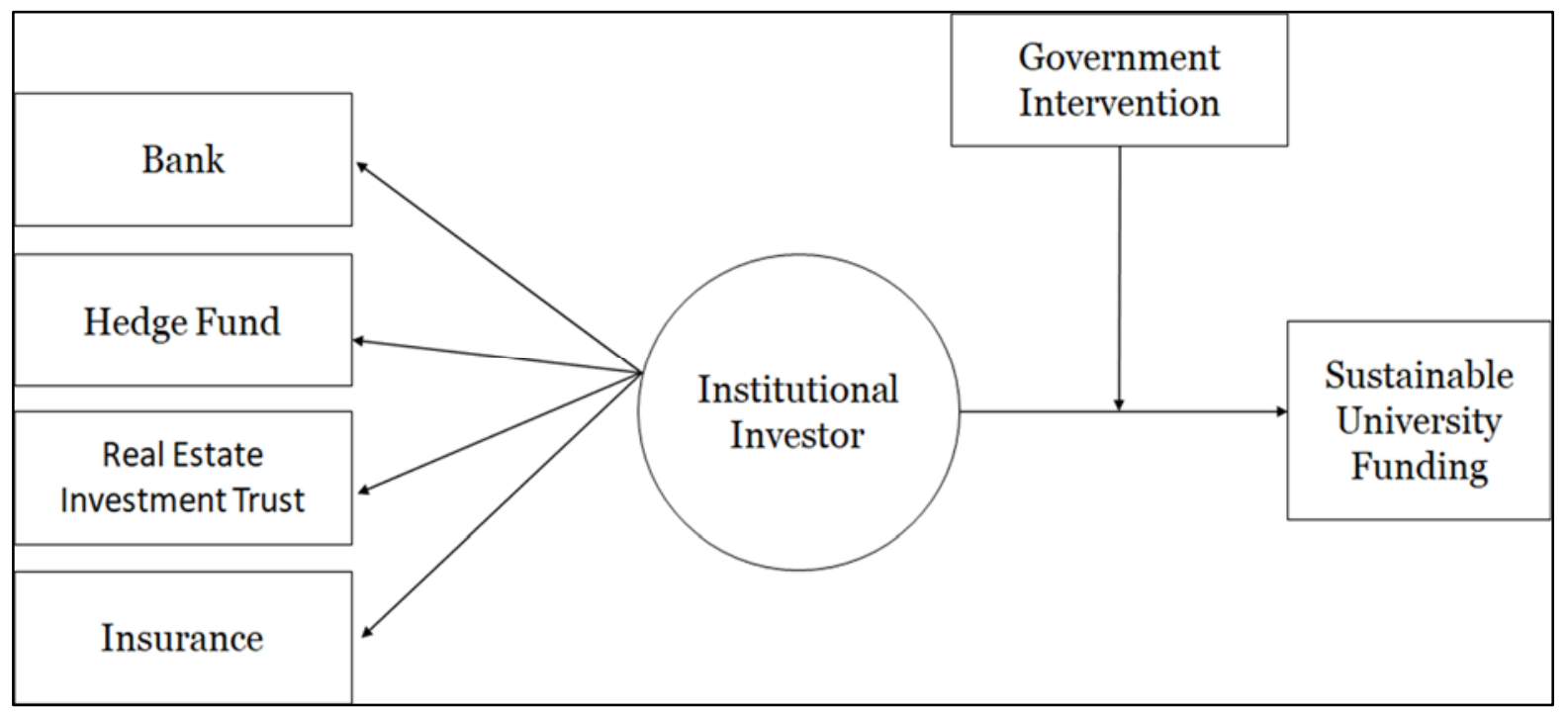

Figure 8. Moderation of Government Intervention in Institutional Investor \& Sustainable University Sustainable Funding.

The Institutional Investor and Sustainable University Funding Governance Code (IISUF Code) along with government intervention, will implement the required policies and procedures, preventing insider trading, abuse of power, corruption, and managing conflicts of interest of parties.

In this proposed code, board-level governance, academic faculties, an academic senate, a corporate board, trustees or stakeholders, and respective institutional investors can be needed to avoid misrepresentation and conflicts amongst stakeholders. This proposed code will be under the law of the Saudi Council of Higher Education and Universities and requires collaboration with an investment law body. The next level of governance Saudi Council of Higher Education and Universities, for policy formulation and implementation of the Institutional Investor \& Sustainable University Funding Governance Code (II-SUF Code), will further ensure security for institutional investors and Saudi universities.

There is merit in inviting institutional investors to support and invest in the Saudi education system, as there is verifiable evidence and examples of successful investment in other industries. These examples include the growth of the Indian stock market [60], successful financing of clean energy infrastructure, entrepreneurial development, poverty 
reduction [56] increasing undertaking of corporate social [62], and improving firm performance [75]. There is also other evidence suggesting the positive correlation between institutional investors and social development, such as improvement of corporate governance quality [63], achieving sustainable development goals [64] and mitigating climate risks [76].

Similarly, the institutional investor has a major role to play in developing and transforming the higher education system, as the future of higher education will be based on industry. For instance, Apple's university-style training program is a unique example of the corporate university and in the future due to the limited resources, the industry and university will be closed for not only enhancing the traditional classroom approach but also enriching the industrial skill in colleges/universities.

Therefore, the intervention of government in the Institutional Investor \& Sustainable University Funding will make this transformation happen and manage the conflict of interest amongst the stakeholders.

\section{Alternative Investment Opportunity for Institutional Investment}

Saudi Arabia's Ministry of Education (MOE) aims to narrow the gap between the output from universities and institutions of higher education (graduates) and their industry's overall needs. By 2030, Saudi Arabia is also aiming for five of its existing universities to be listed in the world's top 200 universities. Additionally, it is expected that by the end of 2030, the qualitative, as well as the quantitative performance of Saudi Arabian students, will exceed the average educational level of international education.

To achieve this, it is highly recommended that an efficient and collaborative joint venture between universities and private institutions be established to enter the Saudi Arabian education market. Further, providing short-term courses or seminars through these institutions is a good way to understand the Saudi education sector market better. The Saudi Arabian government firmly believes that education is the golden key directly linked to progress and improving economic development. Due to this, they have allocated 186 billion rials to the education sector in their 2021 budget—significantly higher than the global average.

Saudi Arabia is one of the most promising markets for investors oriented towards the educational sector [77]. An independent research firm, Ken Research, has predicted that in the next three years, the overall education market in Saudi Arabia alone is likely to grow at a compounded annual growth rate of $12.3 \%$, reaching a relatively large value of US\$15 billion by the end of the year 2021. Conclusively, based on this study model, the next three years must be considered as the best opportunity for potential investors to invest in the Saudi educational market. Therefore, the Institutional Investor and University Sustainable Funding model explores the win-win opportunities for both parties.

Institutional investors should have the opportunity to also maintain a deep understanding of the country's regulatory structure, market size, market growth, and potential of the Saudi Arabia education sector prior to investing in the country's education system. Points to be aware of include:

- Development of the Project for King Abdullah Bin Abdul-Aziz Public Education

- 1376 teaching facilities and schools (411 new schools have been built)

- Innovation between different universities specialized for women's colleges

- The Scholarship Program for students (employee of an institutional investor)

- National Transformation Plan (NTP) associated with the education sector.

Institutional investments by investors such as banks, hedge funds, mutual funds, real estate investment trusts will enhance the financial capability of the education system, which will enable the universities to offer quality education, research \& development, and an all-around innovative culture contributing towards societal development. Not only will inviting institutional investors for alternative funding to the education system to contribute to the university's development, but it will also make the Saudi education system independent, leading to contributing to societal development. Furthermore, 
government funding otherwise directed towards universities can be diverted to other socio-economic development by the university, such as attracting foreign talent for research, inter-university collaboration, industry-university collaboration, and commercializing inventions and patents.

- Why do Institutional Investors Need to Invest in the Education Sector in Saudi Arabia?

There are four significant reasons for institutional investors to invest in the Saudi education market:

1. Saudi Arabia has 29 public universities [78] and 14 private universities.

2. The Saudi government encourages institutional investors to participate in education and plays a key role in education reform by facilitating land, loan, and permit ease procedures.

3. Saudi Arabia is the most significant capital market in the Middle East, North Africa, and Turkey, with a $\$ 450 \mathrm{~B}$ market cap, which directly affects the education market in Saudi Arabia.

4. Realizing the Kingdom's vision of transitioning to on-site digital education in 2030 with 2018 (4266) million dollars in grants [79] and (150) schools replaced by all books printed by the digital department.

\subsection{Alternate Opportunity to the Hedge Funds, Mutual Fund and Insurance}

Before understanding alternate funding, it is crucial to understand hedge, mutual and insurance funds. Hedge and mutual funds are the same in investment terms but different in technicalities. Hedge funds, unlike mutual funds, invest in securities that are not registered in the Capital Market Authority (CMA) and are not required to disclose Annual Net Value (NAV) periodically. In addition, the minimum investment made in hedge funds is 100,000 USD and a longer commitment period. In contrast, there is no minimum limit in terms of investment amount or committed time in mutual funds. Moreover, expense and management fees are higher in hedge funds compared to mutual funds. Investors who deal with hedge funds profit by selling short, which involves high risk and high returns, unlike mutual funds, where investors play safe.

Insurance funds are managed by investment institutions and regulated by the Saudi Arabian Monetary Authority (SAWA). Their business involves using the insurance premium taken from their customers and multiplying it by investing it in the stock market. This applies to all forms of insurance other than life insurance, where they have to return the premium after the policy matures.

Universities can also follow this path and involve financial institutions as a mediator who will manage universities' funds. Institutional investors can use the education sector money as endowment funds and invest it into the stock market. If the government allows for it, universities can also issue an Initial Public Offering (IPO), which will help external and independent investors access publicly listed shares issued in these universities' names. Institutional investors will play the role of an agent, who will manage the funds and earn management fees. However, the education sector in Saudi Arabia, with low cap and high cap, can invest accordingly and earn higher returns. With the implementation of the IISUF model, investment institutions will get another opportunity to take by mobilizing university funds.

\subsection{Opportunity to Invest in Consolidated Investments in the Educational Sector}

The education sector in Saudi Arabia rarely adopts merger strategies due to its relatively young age and high demand, and both tend to be less complex value creation methods. As the education sector matures, this situation will change. In terms of risk and return, the combined business lies between acquisitions focused on growth. Due to integration risks, institutional investors tend to get higher returns than growth-focused acquisitions. Still, compared with Greenland ventures, institutional investors acquire estab- 
lished businesses with a lower risk profile. Generally, the combined value creation plan relies heavily on assets that can be obtained at low multiples. Profits and multiple benefits can be quickly obtained through integration on a more effective platform. Consolidated cash flows usually include monetizing investment increments through some recurring dividends and considerable capital gains on exit.

For instance, in 2005, the Chicago-based stock company founded the Education Futures Association in the southwestern United States, has absorbed and merged several continuing education institutions since its inception. The owner used value creation approaches to release value from the investment until the asset is acquired with the prospect of increasing the margins and promising means of investing in a merger.

The centralization of back-office management functions across several schools, for instance, and the sharing of teacher resources will improve the ratio of teachers and students to managers. It can reduce acquisition costs and raise profit margins for institutional investors by combining vendors and service providers such as consumables, account books, and facility management. Cross-selling of ancillary assets usually creates synergies in terms of sales. Therefore, the 'consolidated investment' in the education sector is an opportunity for institutional investors in Saudi Arabia.

\subsection{Opportunity for 'Real Estate Sale-Leasebacks Investors' in the Educational Sector}

Investment into the current Saudi education sector will create opportunities for institutional investors in real estate, as they can acquire and lease back assets (land and property) for educational institutions that lead to the minimization of capital expenditure and risk minimization. The real estate institutional investors' sale and leaseback are universally accepted at the lower end of the risk/return range, providing a cash flow profile that is bond-like, including regular dividends from rental income and return of investment capital following the disposal of assets. In particular, the educational infrastructure sub-sector, and the parks of entities operating in the education delivery sub-sector, are the best targets for the repurchase of institutional real estate investors. These investments provide buyers and sellers with advantages: the buyer gets predictable long-term returns, usually between $9 \%$ and $11 \%$. For growth and/or distribution, the seller releases free capital locked in non-core assets and improves the return on equity of its operations.

Due to the risks inherent in single-tenant leases, the choice of assets is critical to ensuring that target returns are achieved. Institutional investors should look for universities and higher education institutions and financially sound operators and have a strong position in the established Saudi education market. To determine the property's condition and maintenance history, a thorough property inspection is also essential to eliminate unexpected maintenance that could lead to unforeseen expenditures; this will help limit return leakage.

A long-term lease agreement with the Saudi education investment agency, which is inflation-protected and based on a price index, should be negotiated by institutional investors after the asset selection is completed. To ensure that returns are realized, institutional investors should also monitor facility management costs closely. Here, the ability to achieve scale in a city or region can improve the ability of the buyer to negotiate and reduce operating expenses, just like playing a role in a merger. Therefore, 'real estate saleleasebacks investment' in the education sector is an opportunity for institutional investors in Saudi Arabia.

\subsection{CSR Investment Opportunity (Mitigating Industry-Education Gap)}

In English professional development courses, institutional investors in Saudi Arabia can easily seek opportunities. 'Technical English' courses and practical training and guidance towards machine tools, heavy metal processing, electromechanical, and automotive machinery are the prime focus of these courses. The government prioritizes providing high-demand skills to the younger generation and courses to meet Saudi's industry-specific needs. Computer technology, computer programming, technical and vocational training, 
office management, accounting, financial management, marketing, and sales are among the most popular courses. Saudi market opportunities in general also include both shortterm and long-term training for training upcoming pilots and maintenance of aviation. In addition, training in medical fields such as nursing, X-ray technology, emergency aviation, medical aid, pharmacy, and medical science is also in high demand (undergraduate and graduate level). Mitigating the industry-academia gap will be termed as Corporate Social Responsibility (CSR) [80-82], where universities will be required to invest a certain percentage of their income into a weaker section of society or to a Non-Government Organization (NGO). The youth (weaker section) will get a quality education and find gainful employment. This will lead to improving brand image, and in the future, researchers can also evaluate individual universities' performance empirically through CSR scores. Conclusively, this research will benefit both universities and institutional investors in the Saudi educational market.

\section{Open Approach: The Possibility in Higher Education System}

The open approach in every area of research is gaining momentum as there is an emerging need for an open approach. For instance, in startups [83], product development [84], in innovation ecosystems [84] digital business [85], and similarly, open innovation for value creation amongst [7] university and industry. This research has implications mainly practical and for literature and policymakers, which are discussed in the following section.

\subsection{Practical Implications}

The world has great expectations for how the private sector, which consists of both companies and investors, can support the sustainable development goals (SDGs) [86,87], and from the above discussion in the literature, the nexus of institutional investors with university sustainable funding and moderation role of government intervention suggests that the adoption of institutional investor and sustainable university funding model is crucial, as it requires continuous planning, implementing, monitoring, as well as managing the institutional investors for alternative funding to the education system.

This proposed research model for alternative funding will boost the university's (and, by extension, the education system's) capabilities in infrastructure development, faculty development, and laboratories, which will generate returns in the form of publications, patents, and commercialization of the university's discoveries and inventions. This research model will also bring industries more practical and most needed research-focused solutions. For instance, a few exemplary universities have already initiated this model partially with multinational companies (MNCs) rather than institutional investors. In this undertaking of the model, multinational companies' research and development have been conducted in university laboratories such as King Fahad University, Panasonic Research Centre in the University of Tokyo, and PETRONAS Research Centre at Universiti Teknologi PETRONAS Malaysia. This partial adoption of investment or funding by multinational companies has helped these universities bridge the gap between academia and industry, and as a result, the university rankings of King Fahad University, University of Tokyo, and Universiti Teknologi PETRONAS Malaysia have seen good progress in the last few years.

Another example of partial adoption of our proposed model is offering research grants; many multinational companies support research projects and laboratories to solve their company's problems. This research grants model has many instances of successful implementation. For instance, Nonwovens Institute (NWI) at NC State University, a Sustainable Industry/University/Government Partnership Model since 1991, Procter \& Gamble/University of Cincinnati Simulation Center since 2008, Kansas State University and Abaxis Inc in 2011, and the International Food Safety Training Laboratory (IFSTL), which is a partnership between the University of Maryland \& the Waters Corporation signed in 2010 to Support Sustainable Development. Therefore, this research model is viable for practical application and offers investors real and sustainable funding opportunities. 


\subsection{Academic}

This Institutional Investor and Sustainable University Funding Research Model indicates a new angle of research in institutional investors and alternative funding for universities where more research is required to explore the possibility and process for implementing the model. Although several studies advocated university-industry collaboration [7,88-91], this research extends new possibilities in the literature to bridge the gap between industry and educational institutions, bringing greater opportunity for institutions to invest and develop alternative funding for educational institutions for quality education.

The United Nations SDG-4 also understands the importance of quality education; this research practically pulls the investment from the market and creates a collaborative approach to achieving the target.

This SDG's collaborative approach with the institutional investors will minimize the college's dropouts; once the dropout number decreases, the focus on quality education will enhance gradually.

The research model will also be able to address SDG-4's major seven targets [92] that deal with quality and equality for different phases of education. The first three targets are intended to ensure all children and adults access to quality education from early years through primary and secondary school to technical and university levels. Target 4.4 aims to enhance the practical skills of youth. Target 4.5 is concerned with the distribution of educational access across a range of demographics, noting the needs of people with disabilities, indigenous peoples, and vulnerable groups. Target 4.6 aims to ensure literacy and numeracy for all youth and substantially reduce adult illiteracy. Target 4.7 is the only target that deals with the content of education aiming to develop knowledge and skills for sustainable development, human rights, gender equality, and cultures of peace and non-violence [93].

The proposed model implementation will vary differently in developed, developing, and under developing countries due to the different set of challenges; however, investment in quality education will lead to the achievement of the other 16 sustainable development goals and their 162 targets.

\subsection{Policy Implications}

The research also emphasizes the role of policymakers as this Institutional Investor and Sustainable University Funding Model by understanding the role played in the past in various community and scientific projects [94]. This research model is impractical if the authorities do not invite institutional investors to begin funding the educational sector. This research model will create a win-win situation for both parties, as it also decreases the burden on government expenditure. Moreover, R\&D's social return rate is considered better than the financial return rate as it will bring profit and societal development. Furthermore, this provides a good incentive for the public to endorse R\&D; this spillover impact is considered especially significant in academic science since researchers have a strong desire to make their results public and commercial. Policymakers may rethink their approach, as instead of providing greater tax relief for $R \& D$ in general, there is potential for greater tax relief for university-industry spending on $R \& D$, especially because intellectual property rights are not granted to sponsors.

This research can play a vital role in knowledge acquisition from industry, which provides returns to the institutional investors and the education system and the country's economic and social development. Likewise, this research model also benefits the policymakers of Saudi Arabia, by helping them find opportunities for institutional investors and blue ocean leadership to explore investment opportunities in the Kingdom. It will create potential financing and investment prospects for Saudi Arabia's private investors in the education sector [95].

Lastly, apart from the investment-funding opportunity, the role of policymakers is also imperative in achieving the sustainable development goals concerning quality education (SDG-4) through the proposed model as the implementation requires planning, and gover- 
nance, from the policymakers and government. Government intervention is also crucial in the proposed research model as it requires long-term implementation and monitoring to improve literacy and quality education.

Therefore, Institutional Investor and Sustainable University Funding codes need to be developed favoring the idea of attracting an institutional investor toward sustainable university fundings, which will not only generate more funding but also add new stakeholders in promoting quality education SDG-4.

\section{Conclusions}

Investment in the education system depicts the potential growth and innovation culture of any country in the world. Positive examples are institutional investment in the development financing of clean energy infrastructure, entrepreneurial development, poverty reduction, and driving corporate social responsibility and firm development. This alternative funding opportunity bridges the gap in institutional investors' literature and funding opportunities in the education system. This research proposes alternative sustainable funding for the Saudi education system and investment opportunities for an institutional investor with the moderation of government intervention. This research claims that by government initiative, universities will be able to create an alternative funding source through institutional investors, which will ease the burden on the Saudi government and create huge market opportunities for institutional investors.

To implement the Institutional Investor \& Sustainable University Funding Research Model, the author predicts the role of the Saudi Arabia government will be crucial as this can privatize the education of the Saudi Arabia citizen, along with an economy and education booster. This research model will divert local, sustainable investors from saturated industries towards the education system. The performance evaluation of universities will also change from the traditional approach to the public-listed firm evaluation approach.

To conclude, the Institutional Investor and Sustainable University Funding Research Model can be run as a pilot project. The results can be analyzed to evaluate the performance of institutional investors and the Saudi education system. The high demand for private and public education is attributed to the rise in the number of students, the increase in discretionary income, market preference for private education, and the Saudi government's Ministry of Education (MOE) privatization program. This Institutional Investor and Sustainable University Funding Research Model will enhance the Saudi education system and contribute directly to SDG-4-quality education.

In order to take advantage of these purchases though, institutional investors in Saudi will have to take into account the methods of value formation that can meet the education sector's target returns., as the educational sector shifts, they will pursue expansion plans to release economies of scale and associated rewards and aggressively sustain this research study model. Institutional investors involved in this model stand to earn substantial returns while contributing to the sustainable development goal 4-quality education.

Author Contributions: Conceptualization S.K.J. and P.A.K., literature review P.A.K., S.K.J., S.A. and M.A. writing—original draft P.A.K., written—review and editing, S.A., A.A.S., T.K. and M.A. All authors have read and agreed to the published version of the manuscript.

Funding: This research is funded by matching fund of UTP Malaysia and Uhamka Indonesia 015ME0-174.

Data Availability Statement: Available on Request.

Acknowledgments: The authors would like to appreciate Universiti Teknologi PETRONAS for providing all support and resources in conducting this research.

Conflicts of Interest: The authors declare no conflict of interest. 


\section{References}

1. Huong, P.T.; Cherian, J.; Hien, N.T.; Sial, M.S.; Samad, S.; Tuan, B.A. Environmental Management, Green Innovation, and Social-Open Innovation. J. Open Innov. Technol. Mark. Complex. 2021, 7, 89. [CrossRef]

2. Semin, A.; Betin, O.; Namyatova, L.; Kireeva, E.; Vatutina, L.; Vorontcov, A.; Bagaeva, N. Sustainable condition of the agricultural sector's environmental, economic, and social components from the perspective of open innovation. J. Open Innov. Technol. Mark. Complex. 2021, 7, 2021. [CrossRef]

3. Rodrigues, M.; Alves, M.D.C.; Oliveira, C.; Vale, J.; Silva, R. The impact of strategy, environment, and the management system on the foreign subsidiary: The implication for open innovation. J. Open Innov. Technol. Mark. Complex. 2021, 7, 51. [CrossRef]

4. Prendes-Espinosa, P.; Solano-Fernández, I.M.; García-Tudela, P.A. EmDigital to Promote Digital Entrepreneurship: The Relation with Open Innovation. J. Open Innov. Technol. Mark. Complex. 2021, 7, 63. [CrossRef]

5. Ikram, A.; Fiaz, M.; Mahmood, A.; Ahmad, A.; Ashfaq, R. Internal corporate responsibility as a legitimacy strategy for branding and employee retention: A perspective of higher education institutions. J. Open Innov. Technol. Mark. Complex. 2021, 7, 52. [CrossRef]

6. de las Heras-Rosas, C.; Herrera, J. Research trends in open innovation and the role of the university. J. Open Innov. Technol. Mark. Complex. 2021, 7, 29. [CrossRef]

7. Osorno-Hinojosa, R.; Koria, M.; Ramírez-Vázquez, D.D.C. Open Innovation with Value Co-Creation from University-Industry Collaboration. J. Open Innov. Technol. Mark. Complex. 2022, 8, 32. [CrossRef]

8. Helmy, R.; Khourshed, N.; Wahba, M.; Bary, A.A.E. Exploring critical success factors for public private partnership case study: The educational sector in Egypt. J. Open Innov. Technol. Mark. Complex. 2022, 6, 142. [CrossRef]

9. Mascarenhas, C.; Marques, C.S.; Ferreira, J.J.; Galvão, A.R. The influence of research and innovation strategies for smart specialization (Ris3) on university-industry collaboration. J. Open Innov. Technol. Mark. Complex. 2021, 7, 82. [CrossRef]

10. Almazova, N.; Krylova, E.; Rubtsova, A.; Odinokaya, M. Challenges and opportunities for Russian higher education amid COVID-19: Teachers' perspective. Educ. Sci. 2020, 10, 368. [CrossRef]

11. Nguyen, S.; Fishman, R.; Weeden, D.; Harnisch, T. The Impact of COVID-19 on State Higher Education Budgets: A Tracker of Responses from State Higher Education Systems and Agencies. New Am. 2020. Available online: https://files.eric.ed.gov/ fulltext/ED609154.pdf (accessed on 10 December 2021).

12. Aning, B. Economic aspects of the impact of the panademic on higer educational system. Актуальні проблеми природничих $i$ гуманітарних наук у дослідженнях 2021, 3, 222.

13. Aysan, A.F.; Bergigui, F.; Disli, M. Blockchain-based solutions in achieving SDGs after COVID-19. J. Open Innov. Technol. Mark. Complex. 2021, 7, 151. [CrossRef]

14. Jan, A.A.; Lai, F.-W.; Tahir, M. Developing an Islamic Corporate Governance framework to examine sustainability performance in Islamic Banks and Financial Institutions. J. Clean Prod. 2021, 315, 128099. [CrossRef]

15. Khan, P.A.; Johl, S.K.; Singh, P.; Johl, S.K.; Shamim, A.; Nurhayadi, Y.; Wijiharjono, N.; Al-Azizah, U.S. Injecting Green Innovation Reporting into Sustainability Reporting. In SHS Web of Conferences; EDP Sciences: Les Ulis, France, 2021; Volume 124, p. 05003.

16. Khan, P.A.; Johl, S.K. Firm Performance from the Lens of Comprehensive Green Innovation and Environmental Management System ISO. Processes 2020, 8, 1152.

17. Khan, P.A.; Johl, S.K. Nexus of Comprehensive Green Innovation, Environmental Management System-14001-2015 and Firm Performance. Cogent Bus. Manag. 2019, 6, 1. [CrossRef]

18. Jan, A.; Mata, M.N.; Albinsson, P.A.; Martins, J.M.; Hassan, R.B.; Mata, P.N. Alignment of islamic banking sustainability indicators with sustainable development goals: Policy recommendations for addressing the covid-19 pandemic. Sustainability 2021, 13, 2607. [CrossRef]

19. Toha, M.; Johl, S.K.; Khan, P.A. Firm's Sustainability and Societal Development from the Lens of Fishbone Eco-Innovation: A Moderating Role of ISO 14001-2015 Environmental Management System. Processes 2020, 8, 1152. [CrossRef]

20. Khan, P.A.; Johl, S.K.; Johl, S.K. Does adoption of ISO 56002-2019 and green innovation reporting enhance the firm sustainable development goal performance? An emerging paradigm. Bus. Strateg Environ. 2021, 30, 2922-2936. [CrossRef]

21. Jan, A.A.; Lai, F.W.; Draz, M.U.; Tahir, M.; Ali, S.E.A.; Zahid, M.; Shad, M.K. Integrating sustainability practices into islamic corporate governance for sustainable firm performance: From the lens of agency and stakeholder theories. Qual Quant. 2021, 1-24. [CrossRef]

22. Khan, P.A.; Johl, S.K.; Akhtar, S. Firm Sustainable Development Goals and Firm Financial Performance through the Lens of Green Innovation Practices and Reporting: A Proactive Approach. J. Risk Financ. Manag. 2021, 14, 605. [CrossRef]

23. Lai, F.-W.; Shad, M.K.; Shah, S.Q.A. Conceptualizing Corporate Sustainability Reporting and Risk Management Towards Green Growth in the Malaysian Oil and Gas Industry. In SHS Web of Conferences; EDP Sciences: Les Ulis, France, 2021; Volume 124, p. 04001.

24. Shah, S.A.A.; Shah, S.Q.A.; Tahir, M. Determinants of $\mathrm{CO}_{2}$ emissions: Exploring the unexplored in low-income countries. Environ Sci. Pollut. Res. 2022, 1-9. [CrossRef] [PubMed]

25. Khan, P.A.; Johl, S.K.; Akhtar, S. Vinculum of Sustainable Development Goal Practices and Firms' Financial Performance: A Moderation Role of Green Innovation. J. Risk Financ. Manag. 2022, 15, 96. [CrossRef]

26. Logachev, M.S.; Orekhovskaya, N.A.; Seregina, T.N.; Shishov, S.; Volvak, S.F. Information system for monitoring and managing the quality of educational programs. J. Open Innov. Technol. Mark. Complex. 2021, 1, 93. [CrossRef] 
27. Sariene, L.S.; Perez, C.C.; Hernandez, A.M.L. Expanding the actions of Open Government in higher education sector: From web transparency to Open Science. PLoS ONE 2020, 15, e0238801. [CrossRef] [PubMed]

28. Priyadarshini, P.; Latha, N. Initiatives in Higher Education: Government of India. Date Fac. Dep. Coord. $2019,2,107$.

29. Howell, C. Participation of students with disabilities in South African higher education: Contesting the uncontested. In Education and Disability in the Global South: New Perspectives from Africa and Asia; Bloomsbury Publishing: London, UK, 2018 ; pp. 127-143.

30. Kiel, G.C.; Nicholson, G.J. Board composition and corporate performance: How the Australian experience informs contrasting theories of corporate governance. Corp. Gov. Int. Rev. 2003, 11, 189-205. [CrossRef]

31. Saudi Arabia's Vision 2030. 2016. Available online: https://www.vision2030.gov.sa/v2030/overview/ (accessed on 10 December 2021).

32. Alqahtani, E.M. Vision 2030 and Family: Saudi Arabian Males'perception after Studying in the United States. Doctoral Dissertation, University of Akron, Akron, OH, USA, 2020.

33. Ferguson, T.; Roofe, C.G. SDG 4 in higher education: Challenges and opportunities. Int. J. Sustain. High. Educ. 2020, 21, 959-975. [CrossRef]

34. Khandelwal, C.; Kumar, S.; Verma, D.; Singh, H.P. Financial risk reporting practices: Systematic literature review and research agenda. Bottom Line 2019, 32, 185-210. [CrossRef]

35. Ramírez-Montoya, M.S.; Castillo-Martínez, I.M.; Sanabria-Z, J.; Miranda, J. Complex thinking in the framework of Education 4.0 and Open Innovation-A systematic literature review. J. Open Innov. Technol. Mark. Complex. 2022, 8, 4. [CrossRef]

36. Kroon, N.; Alves, M.D.C.; Martins, I. The Impacts of Emerging Technologies on Accountants' Role and Skills: Connecting to Open Innovation-A Systematic Literature Review. J. Open Innov. Technol. Mark. Complex. 2021, 7, 163. [CrossRef]

37. Rupp, M.; Schneckenburger, M.; Merkel, M.; Börret, R.; Harrison, D.K. Industry 4.0: A technological-oriented definition based on bibliometric analysis and literature review. J. Open Innov. Technol. Mark. Complex. 2021, 7, 68. [CrossRef]

38. Zahaikevitch, E.V.; Macedo, L.M.; Telles, L.B.; Bittencourt, J.V.M.; Zahaikevitch, A.G.V. Contemporary Public Policies to Strengthen Family Farming in the International Perspective: A Bibliometric Study. J. Open Innov. Technol. Mark. Complex. 2002, 8, 8. [CrossRef]

39. Sabando-Vera, D.; Yonfa-Medranda, M.; Montalván-Burbano, N.; Albors-Garrigos, J.; Parrales-Guerrero, K. Worldwide Research on Open Innovation in SMEs. J. Open Innov. Technol. Mark. Complex. 2022, 8, 20. [CrossRef]

40. Kaminker, C.; Stewart, F. The Role of Institutional Investors in Financing Clean Energy. 2012. Available online: https://www. oecd.org/finance/WP_23_TheRoleOfInstitutionalInvestorsInFinancingCleanEnergy.pdf (accessed on 10 December 2021).

41. Aggarwal, R.; Hu, M.; Yang, J. Fraud, market reaction, and the role of institutional investors in Chinese listed firms. J. Portf. Manag. 2015, 41, 92-109. [CrossRef]

42. Michaely, R.; Popadak, J.; Vincent, C. The Deleveraging of US Firms and Institutional Investors' Role. 2015. Available online: https: / / ssrn.com/abstract=1941902 (accessed on 10 December 2021).

43. García-Meca, E.; Pucheta-Martínez, M.C. How institutional investors on boards impact on stakeholder engagement and corporate social responsibility reporting. Corp. Soc. Responsibil. Environ. Manag. 2018, 25, 237-249. [CrossRef]

44. Ameli, N.; Drummond, P.; Bisaro, A.; Grubb, M.; Chenet, H. Climate finance and disclosure for institutional investors: Why transparency is not enough. Clim Chang. 2020, 160, 565-589. [CrossRef]

45. Akhtar, S.; Khan, T.; Khan, P.A. Examine the key drivers affecting bottom line: A panel estimation study of indian commercial bank. J. Crit. Rev. 2020, 7,9.

46. Ruiz, J.L. Financial development, institutional investors, and economic growth. Int. Rev. Econ. Financ. 2018, 54, 218-224. [CrossRef]

47. Tahir, M.; Jan, A.A.; Shah, S.Q.A.; Alam, M.B.; Afridi, M.A.; Tariq, Y.B.; Bashir, M.F. Foreign inflows and economic growth in Pakistan: Some new insights. J. Chin. Econ. Foreign Trade Stud. 2020, 13, 97-113. [CrossRef]

48. Inderst, G. Social Infrastructure Finance and Institutional Investors. A Global Perspective. Glob. Perspect. 2020. Available online: https:/ / papers.ssrn.com/sol3/papers.cfm?abstract_id=3556473 (accessed on 10 December 2021).

49. García-Sánchez, I.M.; Rodríguez-Ariza, L.; Aibar-Guzmán, B.; Aibar-Guzmán, C. Do institutional investors drive corporate transparency regarding business contribution to the sustainable development goals? Bus. Strategy Environ. 2020, 29, 2019-2036. [CrossRef]

50. le Luong, P.; Ha, D.T.T. Behavioral Factors Influencing Individual Investors' Decision-Making and Performance: A Survey at the Ho Chi Minh Stock Exchange. Available online: http:/ / www.diva-portal.org/smash/get/diva2:423263/FULLTEXT02.pdf (accessed on 10 December 2021).

51. Venkataraman, S. The distinctive domain of entrepreneurship research. In Seminal Ideas for the Next Twenty-Five Years of Advances; Emerald Publishing Limited: Bingley, UK, 2019.

52. McCann, L.; Hutchison, N.; Adair, A. External funding of major capital projects in the UK Higher Education sector: Issues of demand, supply and market timing? J. Prop. Res. 2019, 36, 97-130. [CrossRef]

53. Irikana, D.G.; Weli, S. Analysis of Constraints and Strategies in Funding Educational Sector for Academic Performance in Secondary Schools in Rivers State. 2019. Available online: https://seahipaj.org/journals-ci/dec-2019/IJIER/full/IJIER-D-1-2019 .pdf (accessed on 10 December 2021).

54. Hovey, M.; Santiago, M.; Porr, C. Sustaining Experiential Education in a University Agriculture Program Using Alternative Funding Sources and Strategic Planning. NACTA J. 2018, 62, 3. 
55. Usman, M.; Rahman, A.A. Funding higher education through waqf: A lesson from Pakistan. Int. J. Islam. Middle East. Fianc.Manag. 2020, 14, 409-424. [CrossRef]

56. Yusuf, H.O.; Idoghor, U. Community support as an alternative and complementary source of funding basic education in Nigeria. Eur. J. Educ. 2020, 6. Available online: https:/ / www.semanticscholar.org/paper/COMMUNITY-SUPPORT-AS-AN-ALTERNATIVEAND-SOURCE-OF-Yusuf-Idoghor/13b02a7af9026760d202e9b5d8f29ea402b7989f (accessed on 10 December 2021).

57. Riyaldi, M.H.; Yusran, J. Effectiveness of Zakat Funding for Education in Aceh: An Evaluation. In Proceedings of the 2nd Aceh Global Conference on Business Economics, and Sustainable Development Trends (AGC-BEST) 2019, Banda Aceh, Indonesia, 17-18 October 2019; Volume 2, p. 117.

58. Eichner, C. Local Equitable Funding Reform in Education: Washington State Case Study. PhD. Thesis, Northeastern University, Boston, MA, USA, 2020.

59. Mangla, S.K.; Luthra, S.; Jakhar, S.; Gandhi, S.; Muduli, K.; Kumar, A. A step to clean energy-Sustainability in energy system management in an emerging economy context. J. Clean Prod. 2020, 242, 118462. [CrossRef]

60. Kumar, S. Role of Institutional Investors in Indian Stock Market. 2007. Available online: http://dspace.iimk.ac.in/xmlui/ bitstream/handle/2259/392/sss\%2Bkumar.pdf?sequence=1\&isAllowed=y (accessed on 10 December 2021).

61. Goel, S.; Karri, R. Entrepreneurial aspirations and poverty reduction: The role of institutional context. Entrep. Reg. Dev. 2020, 32, 91-111. [CrossRef]

62. Li, Z.; Wang, P.; Wu, T. Do foreign institutional investors drive corporate social responsibility? Evidence from listed firms in China. Bus. Financ. Account. 2021, 48, 338-373. [CrossRef]

63. Chung, C.Y.; Kim, D.; Lee, J. Do Institutional Investors Improve Corporate Governance Quality? Evidence From the Blockholdings of the Korean National Pension Service. Glob. Ecol. Rev. 2020, 49, 422-437. [CrossRef]

64. Yoshino, N.; Taghizadeh-Hesary, F.; Otsuka, M. Covid-19 and optimal portfolio selection for investment in sustainable development goals. Financ. Res. Lett. 2021, 38, 101695. [CrossRef] [PubMed]

65. Ilhan, E.; Krueger, P.; Sautner, Z.; Starks, L.T. Climate risk disclosure and institutional investors. Swiss Financ. Inst. Res. Pap. 2020, 1,19-66.

66. Chirambo, D. Towards the achievement of SDG 7 in sub-Saharan Africa: Creating synergies between Power Africa, Sustainable Energy for All and climate finance in-order to achieve universal energy access before 2030. Renew. Sustain. Energy Rev. 2018, 94, 600-608. [CrossRef]

67. van Loon, J.; Aalbers, M.B. How real estate became 'just another asset class': The financialization of the investment strategies of Dutch institutional investors. Eur. Plan. Stud. 2017, 25, 221-240. [CrossRef]

68. Almahdi, H.K. Promotion and participation of Saudi universities towards the development of entrepreneurial leadership-An empirical study in Saudi Arabian context. J. Entrep. Educ. 2019, 22, 1-14.

69. Kyari, A.K. Managing Urbanisation through Planned Government Expenditure Evidence from Nigeria. In Urbanization and Its Impact on Socio-Economic Growth in Developing Regions; IGI Global: Hershey, PA, USA, 2018; pp. 107-129.

70. Mutalimov, V.; Volkovitckaia, G.; Buymov, A.; Syzdykov, S.; Stepanova, D. Entrepreneurship education: Start-up as a tool for actualizing student's professional competencies. J. Entrep. Educ. 2020, 23, 1-13.

71. Saptono, A. Entrepreneurship education and its influence on financial literacy and entrepreneurship skills in college. J. Entrep. Educ. 2018, 21, 1-11.

72. Šubic, R.; Braje, I.N.; Žagi, K. Family background and financial literacy as a prerequisite for entrepreneurial intention of university students. In Proceedings of the FEB Zagreb International Odyssey Conference on Economics and Business: Zagreb, Opatija, Croatia, 12-15 June; 2019; Volume 1, pp. 678-689.

73. Pikos-Sallie, T.J. The Personal and Professional Benefits and Challenges for Saudi Academics after Postgraduate Study Abroad: Implications for Higher Education Reform in the Kingdom of Saudi Arabia. Ph.D. Thesis, Murdoch University, Perth, Australia, 2018.

74. Shika, H.A. Funding of Education in Nigeria: The Role of Government and Allied Stakeholders. Available online: https://www.academia.edu/44370136/FUNDING_OF_EDUCATION_IN_NIGERIA_THE_ROLE_OF_GOVERNMENT_ AND_ALLIED_STAKEHOLDERS (accessed on 10 December 2021).

75. McCahery, J.A.; Sautner, Z.; Starks, L.T. Behind the scenes: The corporate governance preferences of institutional investors. J. Financ. 2016, 71, 2905-2932. [CrossRef]

76. Choi, D.; Choi, P.M.S.; Choi, J.H.; Chung, C.Y. Corporate governance and corporate social responsibility: Evidence from the role of the largest institutional blockholders in the Korean market. Sustainability 2020, 12, 1680. [CrossRef]

77. Mitchell, B.; Alfuraih, A. The Kingdom of Saudi Arabia: Achieving the aspirations of the National Transformation Program 2020 and Saudi vision 2030 through education. J. Educ. Educ. Dev. 2018, 2, 36. [CrossRef]

78. Aldiab, A.; Chowdhury, H.; Kootsookos, A.; Alam, F. Prospect of eLearning in higher education sectors of Saudi Arabia: A review. Energy Procedia 2017, 110, 574-580. [CrossRef]

79. Alangari, N.K.; Alzamil, W.S. Evaluating the Building Technology Stimulus Initiative Offered by Ministry of Housing within the Kingdom's Vision 2030. J. Sustain. Dev. 2020, 13, 115. [CrossRef]

80. Ahmad, J.; Taib, F.M.; Jan, A. Exploring CSR Initiatives to Cultivate and Nurture Values in Facing Issues Related to Drugs Abuse Among the Youth in Malaysia: Using Three Core Components of Triple Bottom Line (TBL). Bus. Manag. Strategy 2021, 12, 133-144. [CrossRef] 
81. Zahid, M.; Rahman, H.U.; Ali, W.; Khan, M.; Alharthi, M.; Qureshi, M.I.; Jan, A. Boardroom gender diversity: Implications for corporate sustainability disclosures in Malaysia. J. Clean Prod. 2020, 244, 118683. [CrossRef]

82. Ahmad, J.; Taib, F.M.; Jan, A. Employment of Ex-Drug Addicts as a Corporate Social Responsibility Initiative: The Malaysian Employer's Perspective. Available online: https:/ /pdfs.semanticscholar.org/1203/1d5875929e75064c97814386bcb8a20254b7.pdf (accessed on 10 December 2021).

83. Ziakis, C.; Vlachopoulou, M.; Petridis, K. Start-Up Ecosystem (StUpEco): A Conceptual Framework and Empirical Research. J. Open Innov. Technol. Mark. Complex. 2022, 8, 35. [CrossRef]

84. Venesz, B.; Dőry, T.; Raišienè, A.G. Characteristics of Lead Users in Different Stages of the New Product Development Process: A Systematic Review in the Context of Open Innovation. J. Open Innov. Technol. Mark. Complex. 2022, 8, 24. [CrossRef]

85. Tutak, M.; Brodny, J. Business Digital Maturity in Europe and Its Implication for Open Innovation. J. Open Innov. Technol. Mark. Complex. 2022, 8, 27. [CrossRef]

86. Jan, A.; Marimuthu, M.; Mohd, M.P.B.; Isa, M. The nexus of sustainability practices and financial performance: From the perspective of Islamic banking. J. Clean Prod. 2019, 228, 703-717. [CrossRef]

87. Betti, G.; Consolandi, C.; Eccles, R.G. The relationship between investor materiality and the sustainable development goals: A methodological framework. Sustainability 2018, 10, 2248. [CrossRef]

88. Fernandes, G.; O'Sullivan, D. Benefits management in university-industry collaboration programs. Int. J. Proj. Manag. 2021, 39, 71-84. [CrossRef]

89. Melnychuk, T.; Schultz, C.; Wirsich, A. The effects of university-industry collaboration in preclinical research on pharmaceutical firms' R\&D performance: Absorptive capacity's role. J. Prod. Innovat. Manag. 2021, 38, 355-378.

90. Isaeva, I.; Steinmo, M.; Rasmussen, E. How firms use coordination activities in university-industry collaboration: Adjusting to or steering a research center? J. Technol. Transf. 2021, 1-35. [CrossRef]

91. Tian, M.; Su, Y.; Yang, Z. University-industry collaboration and firm innovation: An empirical study of the biopharmaceutical industry. J. Technol. Transf. 2021, 1-18. [CrossRef]

92. Unterhalter, E. The many meanings of quality education: Politics of targets and indicators in SDG 4. Glob. Policy 2019, 10, 39-51. [CrossRef]

93. Mochizuki, Y. Rethinking Schooling for the 21st Century: UNESCO-MGIEP's Contribution to SDG 4.7. Sustain. J. Record 2019, 12, 88-92. [CrossRef]

94. Boeren, E. Understanding Sustainable Development Goal (SDG) 4 on "quality education" from micro, meso and macro perspectives. Inte. Rev. Educ. 2019, 65, 277-294. [CrossRef]

95. Rojec, M.; Knell, M. Why is there a lack of evidence on knowledge spillovers from foreign direct investment? J. Ecol. Sur. 2018, 32, 579-612. [CrossRef] 